\title{
Production of prostaglandin by late-gestation porcine placental cells in vitro
}

\author{
J. F. Burchard ${ }^{1}$, G. C. B. Randall ${ }^{2}$ and B. R. Downey ${ }^{1 *}$ \\ ${ }^{1}$ Department of Animal Science, Macdonald Campus of McGill University, Ste Anne de Bellevue, \\ Quebec, Canada H9X 1C0; and ${ }^{2}$ Animal Diseases Research Institute, Agriculture Canada, Nepean, \\ Ontario, Canada $\mathrm{K} 2 \mathrm{H} 8 \mathrm{P} 9$
}

\begin{abstract}
Summary. Fifteen sows were assigned to three groups of five each, according to gestational age (109 days, 114 days or labour). Two fetuses per sow were chosen at random, and amnion, allantochorion, amniochorion, amniotic fluid and fetal urine were collected. Tissues were enzymatically dispersed and incubated for 1, 2, 3 or $4 \mathrm{~h}$ and the prostaglandin (PG) content of the supernatant medium was measured by radioimmunoassay. In general, all placental cell types produced at least three times more prostaglandin E (PGE) and 6-keto-PGF I $_{1 \alpha}$ than PGF. Production did not vary across gestational age, except that production of 6-keto-PGF ${ }_{1 \alpha}$ was lower in cells collected during labour, resulting in a relative increase in PGF and PGE. Amniochorion cells had a lower de novo capacity to synthesize PG than did allantochorion or amniochorion, whereas treatment of allantochorion with preterm amniotic fluid, preterm or term fetal urine resulted in increased PG output. These results demonstrate that porcine placental cells can synthesize and metabolize prostaglandin in late gestation but suggest that their capacity to produce $\mathrm{PGI}_{2}$ (as measured by 6-keto-PGF $_{1 \alpha}$ ) is lower than for other prostaglandins during labour.
\end{abstract}

Keywords: prostaglandin; placenta; pig; fetal fluids

\section{Introduction}

In many mammalian species, prostaglandins (PGs) are considered to be mediators of events that lead to increased uterine activity during labour (Novy \& Liggins, 1980; Bazer \& First, 1983). In sheep (Thorburn \& Challis, 1979) and sows (Silver et al., 1979; Randall et al., 1986), higher PG concentrations in uterine venous blood than in uterine arterial blood at the end of pregnancy suggest that the gravid uterus is an important source of PGs. Ovine myometrial and placental tissues collected during parturition have a greater capacity for PG production in vitro than those obtained before labour (Mitchell \& Flint, 1978). Bovine placental tissues in late gestation produce PGs in vitro (Gross et al., 1985; Gross \& Williams, 1988), the synthetic capacity differing among tissues (Gross \& Williams, 1988). In pigs, PG production by placental tissues in vitro has not been studied.

This study determined the capacity of late-gestation porcine placental cells to produce PGs in vitro and examined the effects of gestational age and fetal fluids on PG production.

\section{Materials and Methods}

\section{Animals}

Fifteen Yorkshire gilts $(160 \cdot 9 \pm 17 \cdot 3 \mathrm{~kg}$ ) were allocated to three groups according to gestational age (day 109, day 114 (not in labour) or in labour). Sows were designated in labour when the first piglet was delivered vaginally; none of

*Reprint requests. 
the sows used on day 114 showed any of the preparturient behavioural changes that normally precede the myometrial activity associated with labour (Taverne, 1979). Gestational age for the group in labour ranged from 113 to 116 days, with an average of 114.6 days.

\section{Collection of tissue and fluid}

For sample collection, gilts underwent Caesarean sections under general halothane anaesthesia. Two fetuses per sow were chosen at random for sampling. Amniotic fluid uncontaminated with blood and fetal urine was collected, frozen and stored at $-20^{\circ} \mathrm{C}$; approximately $30 \mathrm{ml}^{2}$ of amnion, allantochorion and amniochorion were sampled and transferred to Hank's balanced salt solution (HBSS) at $\mathrm{pH} 7 \cdot 3$, cooled to $4^{\circ} \mathrm{C}$, with $0.035 \%$ sodium bicarbonate.

\section{Cell dispersion}

Tissues from each fetus were minced, transferred to culture tubes, centrifuged for $7 \mathrm{~min}$ at $180 \mathrm{~g}$ and resuspended in HBSS $\left(4 \mathrm{ml} \mathrm{ml}^{-1}\right.$ packed tissue) containing $0.5 \%$ collagenase type II, $0.1 \%$ protease type XIV and $0.1 \%$ hyaluronidase type I-S, and incubated in a shaking water bath at $37^{\circ} \mathrm{C}$ for $2 \mathrm{~h}$ (Marcus et al., 1984). After incubation for $1 \mathrm{~h}$ approximately $1 \mathrm{mg}$ DNAase type I was added to the suspension. Fetal calf serum $(20 \% \mathrm{v} / \mathrm{v})$ was added at the end of the incubation. Cell suspensions were filtered twice through four layers of cheese cloth and centrifuged for $10 \mathrm{~min}$ at $180 \mathrm{~g}$.

Red blood cells were removed by centrifugation of cell pellets in iso-osmotic HBSS containing $52 \% \mathrm{v} / \mathrm{v}$ percoll (Sigma Chemical Co., St Louis, MO, USA) PVP-coated silica (Percoll-Sigma) for $15 \mathrm{~min}$ at $1750 \mathrm{~g}$. Placental cells were washed three times in HBSS and the resulting cell pellets were resuspended in Eagles' minimum essential medium (MEM) supplemented with $1 \% \mathrm{v} / \mathrm{v} 100 \times$ nonessential amino acid solution, 50000 units penicillin $\mathrm{G}$ sodium, $50 \mathrm{mg}$ streptomycin sulfate and $625 \mu \mathrm{g}$ amphotericin B $1^{-1}$ of MEM (Marcus et al., 1984). Cell yield and viability were estimated by diluting an aliquot of the final cell suspension in MEM containing $0.001 \%$ fluorescein diacetate. An overall viability of $87 \%$ was obtained.

\section{Cell incubation}

Cell suspensions were diluted with MEM, with or without additions, to provide $4 \times 10^{5}$ viable cells $\mathrm{ml}^{-1}$. Cells were cultured in 24-well plastic plates (Falcon), with four replicates per time point, for $0,1,2,3$ or $4 \mathrm{~h}$ at $37^{\circ} \mathrm{C}$ under $95 \% \mathrm{O}_{2}$ and $5 \% \mathrm{CO}_{2}$. In addition, allantochorion cells were cultured in MEM containing preterm or term fetal urine or preterm amniotic fluid at a final concentration of $25 \% \mathrm{v} / \mathrm{v}$ for 0 or $4 \mathrm{~h}$ only. Incubation was stopped by storing the cell suspensions at $-20^{\circ} \mathrm{C}$. Before analysis, suspensions were thawed in water cooled to $4^{\circ} \mathrm{C}$ and centrifuged at $2000 \mathrm{~g}$ for $15 \mathrm{~min}$ to remove cell debris.

\section{Radioimmunoassay}

Concentrations of PGs in culture media were estimated without extraction using specific radioimmunoassays for 13,14-dihydro-15 keto-PGF ${ }_{2 \mathrm{u}}$ (PGFM), PGE, PGF and 6-keto-PGF ${ }_{1 \alpha}$ (Olson et al., 1983). As the antibodies to $\mathrm{PGE}_{2}$ $(17 \%)$ and $\mathbf{P G F}_{2 \mathrm{a}}(53 \%)$ reacted with the 1 and 2 series, and $\mathrm{PGFM}$ reacted with $15-\mathrm{keto}-\mathrm{PGF}_{1 \mathrm{a}}(20 \%)$, results are expressed as $\mathrm{PGE}$ and PGF. All other cross reactivities were $<0.5 \%$. Standard solutions $\left(n=4\right.$ dose $\left.^{-1}\right)$ ranging from 12.5 to $500 \mathrm{pg}$ were prepared in $100 \mu \mathrm{l}$ MEM and added to $12 \times 75 \mathrm{~mm}$ culture tubes containing $100 \mu \mathrm{l}$ phosphatebuffered saline $\left(0 \cdot 1 \mathrm{~mol}^{-1}\right)$ with $0 \cdot 1 \%$ gelatin. Subsequently, $100 \mu \mathrm{PG}$ antiserum and $\left.100 \mu 1{ }^{3} \mathrm{H}\right] \mathrm{PG}(5000 \mathrm{c}$.p.m.) in phosphate-buffered saline were added and the tubes were incubated overnight at $5^{\circ} \mathrm{C}$. Bound PG was separated from the free fraction by adding $0.5 \mathrm{ml} 0.5 \%$ dextran-charcoal to the incubates, which were then centrifuged for $10 \mathrm{~min}$ at $1500 \mathrm{~g}$. Radioactivity in supernantants $(0.65 \mathrm{ml})$ was measured for $5 \mathrm{~min}$ in a scintillation counter. Intra- and interassay coefficients of variation varied from 1.9 to $3.6 \%$ and from 20.2 to $28.5 \%$, respectively, for the four PGs measured. All results are expressed as net PG concentrations, i.e. concentration estimated after 1,2,3 or $4 \mathrm{~h}$ of incubation minus that obtained at $0 \mathrm{~h}$ of incubation. An additional subtraction of PG concentrations found in fetal fluids was carried out when cells were treated with any of these fluids.

\section{Statistical analyses}

Data were analysed using the general linear models procedure (SAS, 1982). The effect of sow was nested within gestational age, and fetus was nested within sow and within gestational age. Tissue, incubation period and treatment were cross-classified with fetus within sow within gestational age. Sow and fetus were considered as random effects. Comparisons within effects were carried out using least-squares mean $t$ test. Significant differences were declared at probability levels $<5 \%$ (Steel \& Torrie, 1980). 


\section{Results}

\section{Untreated cells}

Within tissue and gestational age effects, amnion had a lower capacity $(P<0.05)$ to produce PGs than either amniochorion or allantochorion, which did not differ (Tables 1 and 2). Consistent differences due to gestational age within tissues were not detected, with the exception of 6-keto$\mathrm{PGF}_{1 \alpha}$ at labour, for which the concentration was approximately $2 \cdot 5,3$ and 10 times lower $(P<0.05)$ in media of allantochorion, amniochorion and amnion cells, respectively, compared with day 109 (Table 2). A strong tendency towards a lower production of 6-keto-PGF ${ }_{1 \alpha}$ at labour was apparent even at $0 \mathrm{~h}$ (Table 1). Production of PGE, PGFM and 6-keto-PGF ${ }_{1 \alpha}$ tended to increase proportionally with duration of incubation, while PGF appeared to have reached a peak at $2 \mathrm{~h}$ of incubation and then decreased (Table 3). The most abundant PG in the incubates of all tissues was PGE, followed by 6-keto-PGF ; $_{10}$ PGF and PGFM were present in much lower amounts.

Table 1. Least-squares means $( \pm \mathrm{SEM})$ of prostaglandin (PG) concentrations (pg in $4 \times 10^{5}$ cells) at $0 \mathrm{~h}$ in cultures of porcine placental tissues of different gestational ages

\begin{tabular}{|c|c|c|c|}
\hline & Day 109 & Day 114 & Labour \\
\hline \multicolumn{4}{|l|}{ Amnion } \\
\hline PGFM & $96 \cdot 6 \pm 54$ & $102 \cdot 1 \pm 53$ & $60 \cdot 0 \pm 53$ \\
\hline PGE & $1880.5 \pm 843$ & $850 \cdot 2 \pm 855$ & $658.5 \pm 854$ \\
\hline PGF & $556.3 \pm 373$ & $204 \cdot 3 \pm 373$ & $409 \cdot 7 \pm 363$ \\
\hline 6-keto-PGF 10 & $1336 \cdot 3 \pm 767$ & $626 \cdot 7 \pm 715$ & $122.9 \pm 694$ \\
\hline \multicolumn{4}{|l|}{ Allantochorion } \\
\hline PGFM & $112.0 \pm 51$ & $206.0 \pm$ & $142 \cdot 6 \pm 52$ \\
\hline PGE & $4699 \cdot 9 \pm 831$ & $3310 \cdot 1 \pm 833$ & $2438 \cdot 8 \pm 843$ \\
\hline PGF & $1122.5 \pm 378$ & $1031.9 \pm 364$ & $843 \cdot 0 \pm 384$ \\
\hline 6-keto-PGF & $2730 \cdot 0 \pm 767$ & $2676.4 \pm 705$ & $927 \cdot 5 \pm 714$ \\
\hline \multicolumn{4}{|l|}{ Amniochorion } \\
\hline PGFM & $95 \cdot 3 \pm 53$ & $177.8 \pm$ & $122 \cdot 4 \pm 53$ \\
\hline PGE & $4704 \cdot 8 \pm 831$ & $3100 \cdot 5 \pm 1008$ & $2446 \cdot 0 \pm 854$ \\
\hline PGF & $1258 \cdot 0 \pm 367$ & $643 \cdot 1 \pm 430$ & $791 \cdot 7 \pm 385$ \\
\hline 6-keto-PGF $F_{1 \alpha}$ & $2921.6 \pm 767$ & $2910 \cdot 1 \pm 834$ & $938 \cdot 6 \pm 695^{\mathrm{a}}$ \\
\hline
\end{tabular}

${ }^{\text {a }} P<0 \cdot 1$ compared with day 109 or 114 within row.

\section{Treated cells}

Treatment of allantochorion cells from the 15 gilts (30 fetuses) with fetal fluids resulted in a significant change in PG output: treatment with preterm, term fetal urine or preterm amniotic fluid resulted in increased production $(P<0.05)$ of PGE, 6-keto-PGF ${ }_{1 \alpha}$ (Fig. 1(a)) and PGF (Fig. 1 (b)) compared with controls. PGFM did not change with the addition of either preterm fetal urine or amniotic fluid, while term fetal urine reduced $(P<0.05)$ PGFM production (Fig. 1(b)).

\section{Discussion}

These data demonstrate that porcine placental tissues have the capacity to produce PGs in vitro, as do sheep (Mitchell \& Flint, 1978; Evans et al., 1982; Risbridger et al., 1985; Olson et al., 1985) 
Table 2. Least-squares means ( \pm SEM) of net prostaglandin (PG) production (pg in $4 \times 10^{5}$ cells) by porcine placental tissues of different gestational ages after incubation for $4 \mathrm{~h}$

\begin{tabular}{lccc}
\hline & Day 109 & \multicolumn{1}{c}{ Day 114} & \multicolumn{1}{c}{ Labour } \\
\hline Amnion & & & \\
PGFM & $56 \cdot 2 \pm 51$ & $68 \cdot 3 \pm 52$ & $85 \cdot 9 \pm 53$ \\
PGE & $868 \cdot 1 \pm 425$ & $514 \cdot 1 \pm 445$ & $206 \cdot 5 \pm 438$ \\
PGF & $240 \cdot 4 \pm 167$ & $151 \cdot 8 \pm 180$ & $-32 \cdot 2 \pm 173$ \\
6-keto-PGF & $1090 \cdot 6 \pm 191^{\mathrm{b}}$ & $323 \cdot 6 \pm 177$ & $137 \cdot 5 \pm 182^{\mathrm{c}}$ \\
Allantochorion & & & \\
PGFM & $462 \cdot 7 \pm 134^{\mathrm{a}}$ & $286 \cdot 9 \pm 136^{\mathrm{a}}$ & $351 \cdot 4 \pm 134^{\mathrm{a}}$ \\
PGE & $1772 \cdot 5 \pm 501^{\mathrm{a}}$ & $1664 \cdot 9 \pm 501^{\mathrm{a}}$ & $2500 \cdot 0 \pm 517^{\mathrm{a}}$ \\
PGF & $349 \cdot 1 \pm 171$ & $135 \cdot 0 \pm 182$ & $-41 \cdot 3 \pm 191$ \\
6-keto-PGF & $2520 \cdot 9 \pm 382^{\mathrm{a}}$ & $1697 \cdot 5 \pm 358^{\mathrm{a}}$ & $1013 \cdot 5 \pm 358^{\mathrm{ac}}$ \\
Amniochorion & & & \\
PGFM & $412 \cdot 2 \pm 119^{\mathrm{a}}$ & $259 \cdot 5 \pm 140^{\mathrm{a}}$ & $329 \cdot 2 \pm 121^{\mathrm{a}}$ \\
PGE & $3774 \cdot 1 \pm 783^{\mathrm{a}}$ & $2223 \cdot 8 \pm 912^{\mathrm{a}}$ & $2482 \cdot 1 \pm 808^{\mathrm{a}}$ \\
PGF & $625 \cdot 5 \pm 178$ & $305 \cdot 1 \pm 208$ & $44 \cdot 5 \pm 187$ \\
6-keto-PGF & $2513 \cdot 4 \pm 502^{\mathrm{a}}$ & $1978 \cdot 7 \pm 524^{\mathrm{a}}$ & $907 \cdot 0 \pm 464^{\mathrm{ac}}$ \\
\hline
\end{tabular}

${ }^{a} P<0.05$ compared with amnion within gestational age.

${ }^{\mathrm{b}} P<0.05$ compared with day 114 or labour within row.

${ }^{\mathrm{c}} P<0.05$ compared with day 109 within row.

Table 3. Least-squares means ( \pm SEM) of net prostaglandin $(P G)$ production (pg in $4 \times 10^{5}$ cells) by porcine allantochorion of different gestational ages after incubation for $1,2,3$ or $4 \mathrm{~h}$

\begin{tabular}{lcrrrrr}
\hline & & \multicolumn{5}{c}{ Incubation time (h) } \\
\cline { 3 - 6 } & & \multicolumn{1}{c}{1} & \multicolumn{1}{c}{2} & \multicolumn{1}{c}{3} & \multicolumn{1}{c}{4} \\
\hline PGFM & d 109 & $117 \cdot 8 \pm 44$ & $221 \cdot 3 \pm 54$ & $293 \cdot 1 \pm 75$ & $462 \cdot 7 \pm 133$ \\
& d 114 & $50 \cdot 7 \pm 58$ & $126 \cdot 3 \pm 62$ & $207 \cdot 5 \pm 72$ & $286 \cdot 9 \pm 136$ \\
& Labour & $67 \cdot 6 \pm 69$ & $129 \cdot 6 \pm 60$ & $214 \cdot 2 \pm 77$ & $351 \cdot 4 \pm 134$ \\
PGE & d 109 & $1486 \cdot 3 \pm 239$ & $2363 \cdot 8 \pm 436$ & $1835 \cdot 5 \pm 409$ & $1772 \cdot 0 \pm 501$ \\
& d 114 & $993 \cdot 6 \pm 238$ & $1562 \cdot 6 \pm 443$ & $1615 \cdot 0 \pm 416$ & $1664 \cdot 4 \pm 501$ \\
& Labour & $936 \cdot 0 \pm 376$ & $1328 \cdot 0 \pm 497$ & $1740 \cdot 9 \pm 454$ & $2500 \cdot 0 \pm 517$ \\
PGF & d 109 & $284 \cdot 6 \pm 198$ & $658 \cdot 8 \pm 189$ & $566 \cdot 3 \pm 177$ & $349 \cdot 1 \pm 171$ \\
& d I14 & $229 \cdot 1 \pm 226$ & $513 \cdot 8 \pm 200$ & $433 \cdot 2 \pm 175$ & $135 \cdot 1 \pm 182$ \\
& Labour & $245 \cdot 5 \pm 303$ & $274 \cdot 2 \pm 206$ & $263 \cdot 4 \pm 180$ & $-41 \cdot 3 \pm 191$ \\
6-keto-PGF & d 109 & $907 \cdot 3 \pm 382$ & $1004 \cdot 1 \pm 461$ & $1240 \cdot 0 \pm 623$ & $2520 \cdot 9 \pm 382$ \\
& d 114 & $996 \cdot 9 \pm 441$ & $385 \cdot 5 \pm 652$ & $1391 \cdot 3 \pm 593$ & $1697 \cdot 5 \pm 358$ \\
& Labour & $412 \cdot 3 \pm 536$ & $695 \cdot 0 \pm 443$ & $1137 \cdot 4 \pm 602$ & $1013 \cdot 5 \pm 358^{\mathrm{a}}$ \\
\hline
\end{tabular}

${ }^{\mathrm{a}} P<0.05$ compared with day 109 within $\mathrm{PG}$.

and cows (Gross et al., 1985; Gross \& Williams, 1988). Tissues in contact with the endometrium produced significantly more $\mathrm{PGs}$ than the amnion, which is not in contact with it. The predominant PGs produced were PGE and 6-keto-PGF ${ }_{1 \alpha}$, PGs of the F series being produced in small amounts (Tables 1 and 2). This is consistent with the large arteriovenous difference in umbilical plasma concentrations of PGE in pigs (Silver et al., 1979). Negative PGF values after $4 \mathrm{~h}$ of incubation could be attributed to the activity of 15-dehydrogenase-13-14 reductase (Lands, 1979) and/or $\mathrm{PGE}_{2}-9$-keto-reductase (Watson et al., 1979; Niesert et al., 1987) which may enable the cells to convert $\mathrm{PGF}_{2 a}$ into PGFM or PGE, respectively (Table 3). Except for a reduction in output of 


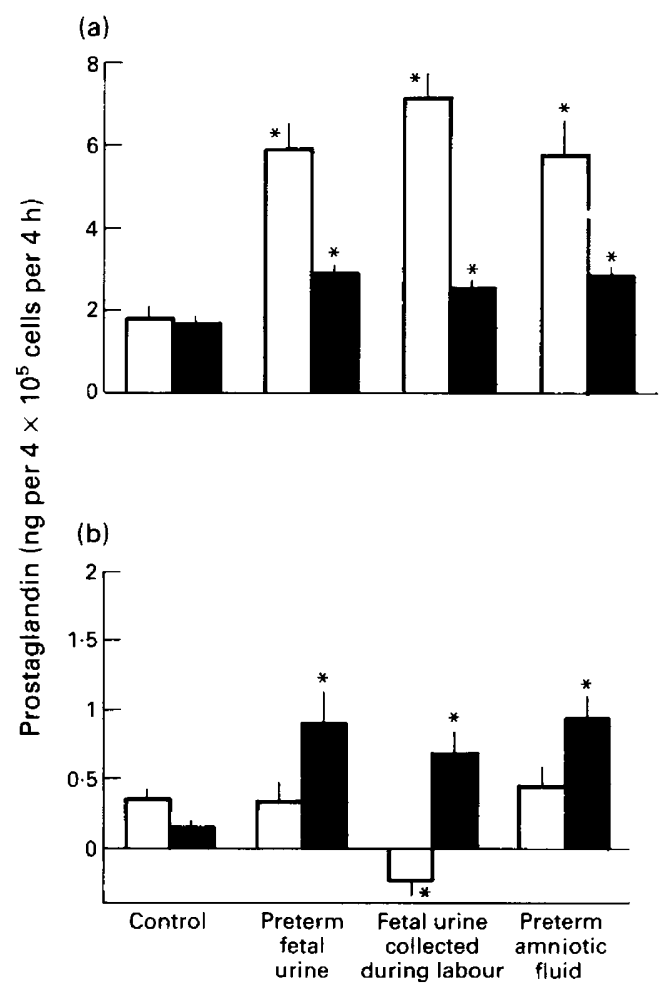

Fig. 1. Least-squares means of net prostaglandin (PG) output by porcine allantochorion treated with various fluids ${ }^{*} P<0.05$ compared with control: (a) ( $\square$ ) PGE and (ם) 6-keto$\mathrm{PGF}_{1 a}$ and (b) ( $\square$ ) PGFM and (ם) PGF.

6-keto-PGF ${ }_{1 \alpha}$ by all cells collected during labour, the capacity of amnion, allantochorion and amniochorion to produce PGs in vitro did not change with gestational age. This is different from reports on sheep (Risbridger et al., 1985; Olson et al., 1984, 1985) and human (Olson et al., 1983), where, in general, the placenta had greater PG synthetic capacity in vitro when collected during labour, although Mitchell (1981) found little variation in placental PG synthetic capacity related to gestational age. The gestational ages selected in the present study covered periods when maternal plasma progesterone concentrations are high (day 109), progesterone and PG concentrations are low (day 114) and PG concentrations are greatest (in labour) (Randall et al., 1986).

The decrease in $\mathrm{PGI}_{2}$ production, as measured by 6-keto- $\mathrm{PGF}_{1 \alpha}$, may reflect selective suppression, which results in a relative increase in PGF and PGE output. $\mathrm{PGI}_{2}$ may inhibit spontaneous uterine activity in humans, sheep and rats (Omini et al., 1978, 1979; Lye \& Challis, 1982; Kawano \& Mori, 1988), although its action in pigs is unknown. This relative decrease of an inhibitory PG during labour could be part of a mechanism to enhance uterine activity, and it may also suggest an independent regulatory mechanism for $\mathrm{PGI}_{2}, \mathrm{PGE}$ and $\mathrm{PGF}$ synthetase.

As PGs are evanescent compounds (Lands, 1979), it is reasonable to expect them to act as local hormones. The allantochorion and amniochorion, which had the highest PG production in vitro, form most of the placenta in this species and are in direct juxtaposition to the endometrium (Noden \& de Lahunta, 1985). This could facilitate the passage of PGs to the endometrium and myometrium. However, little is known about PG movement across the pig placenta and it is not known whether placental PGs act as substrates for the increased uterine PG production seen during labour (Randall et al., 1986). 
Treatment of allantochorion with preterm amniotic fluid, preterm or term fetal urine resulted in an increase in net production of all PGs except PGFM. The increase was greater for PGF than for

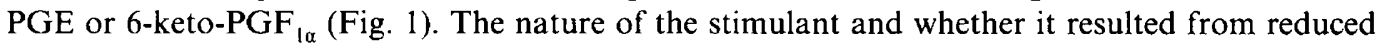
catabolism, increased synthesis or a combination of both cannot be determined from these data. Porcine fetal fluids stimulated PG production in placental cells regardless of gestational age, unlike human fetuses, in which urine obtained during labour had a greater capacity to stimulate PG synthesis (Casey et al., 1983; Strickland et al., 1983) and which may have resulted from the presence of a protein-associated (Casey et al., 1983) or a growth-factor-like substance (Casey et al., 1984) in the fetal urine. Porcine fetal urine and amniotic fluid contain oestrogens during late gestation (Choong \& Raeside, 1974; Robertson et al., 1985) and these have also been shown to stimulate $\mathrm{PGF}_{2 \alpha}$ production by human endometrium in vitro and in vivo (Kelly \& Abel, 1980; Schatz \& Gurpide, 1983; Schatz et al., 1986, 1987). As the fetal urinary bladder connects with the allantoic cavity and the amniotic sac (Noden \& de Lahunta, 1985), fetal urine may have contact with amniochorion and allantochorion cells. If these cells behave in vivo as they do in vitro, these as yet uncharacterized substances in fetal urine may play a role in modulating PG metabolism in the fetal membranes.

We have shown that the porcine placenta produces PGs in abundance, PGE being predominant, and that placental tissues in direct apposition to the endometrium (allantochorion and amniochorion) produce more PGs than the amnion. The lower $\mathrm{PGI}_{2}$ production in cells collected during labour leads to a proportional increase in PGE and PGF. Fetal urine and amniotic fluid have the capacity to stimulate the production of PGs by placental cells, but the stimulatory factor remains to be characterized.

We are grateful to R. Lucis, Y. Barbeau, G. Raby and E. Meredith for technical assistance. Thanks also to T. A. Louis (School of Medicine, East Carolina University), N. R. Mason (Lilly Research Lab., Indianapolis), K. T. Kirton (Upjohn, Kalamazoo) and C. W. Leffler (University of Tennessee, Memphis) for their kind donations of PG antisera.

Supported in part by a grant from le Conseil des recherches en pêche et agroalimentaire du Québec (MCA-86-A-2019).

\section{References}

Bazer, F.W. \& First, N.L. (1983) Pregnancy and parturition Journal of Animal Science (Supplement 2) 57, 425460.

Casey, M.L., MacDonald, P.C. \& Mitchell, M.D. (1983) Stimulation of prostaglandin E-2 production in amnion cells in culture by a substance(s) in human fetal and adult urine. Biochemical and Biophysical Research Communications 114, 1056-1063.

Casey, M.L., MacDonald, P.C. \& Mitchell, M.D. (1984) Stimulation of amnion $\mathrm{PGE}_{2}$ production by a growth factor-like substance in human fetal urine. Journal of Steroid Biochemistry 20, 1417.

Choong, C.H. \& Raeside, J.I. (1974) Chemical determination of oestrogen distribution in the foetus and placenta of the domestic pig. Acta Endocrinologica 77, $171-185$.

Evans, C.A., Kennedy, T.G. \& Challis, J.R.G. (1982) Gestational changes in prostanoid concentration in intrauterine tissues and fetal fluids from pregnant sheep, and the relation to prostanoid output in vitro. Biology of Reproduction 27, 1-11.

Gross, T.S. \& Williams, W.F. (1988) Bovine placental prostaglandin synthesis: principal cell synthesis as modulated by the binucleate cell. Biology of Reproduction 38, 1027-1034.
Gross, T.S., Williams, W.F. \& Manspeaker, J.E. (1985) In vitro placental prostaglandin synthesis in late pregnant and peripartum cow. Biology of Reproduction (Supplement 1) 32, 154 (abstract).

Kawano, M. \& Mori, N. (1988) The significance of prostacyclin produced by pregnant rat myometrium: the relationship between myometrial prostacyclin producing activity and passive stretch of myometrium by growing conceptus. Prostaglandins 35, 305-325.

Kelly, R.D. \& Abel, M.H. (1980) Catechol oestrogens stimulate and direct prostaglandin synthesis. Prostaglandins 20, 613-626.

Lands, W.E.M. (1979) The biosynthesis and metabolism of prostaglandins. Annual Review of Physiology 41, $633-652$.

Lye, S.J. \& Challis, J.R.G. (1982) Inhibition by PGI-2 of myometrial activity in vivo in non-pregnant ovariectomized sheep. Journal of Reproduction and Fertility 66, 3II-315.

Marcus, G.J., Connor, L., Domingo, M.T., Tsang, B.K., Downey, B.R. \& Ainsworth, L. (1984) Enzymatic dissociation of ovarian and uterine tissues. Endocrine Research 10, 152-162. 
Mitchell, M.D. (1981) Prostaglandins during pregnancy and the perinatal period. Journal of Reproduction and Fertility 62, 305-315.

Mitchell, M.D. \& Flint, A.P.F. (1978) Prostaglandin production by intra-uterine tissues from periparturient sheep: use of a superfusion technique. Journal of Endocrinology 76, 111-121.

Niesert, S.T., Mitchell, M.D., Casey, M.L. \& MacDonald, P.C. (1987) Prostaglandin 9-keto-reductase activity in human fetal membranes, uterine decidua vera and myometrium smooth muscle cells. Acta Endocrinologica (Supplement 283), 114, 9.

Noden, R.M. \& de Lahunta, A. (1985) Extraembryonic membranes and placentation. In The Embryology of Domestic Animals, pp. 47-79. Williams \& Wilkins, Baltimore.

Novy, M.J. \& Liggins, G.C. (1980) Role of prostaglandins, prostacyclin and thromboxanes in the physiologic control of the uterus and in parturition. Seminars in Perinatology 4, 45-66.

Olson, D.M., Skinner, K. \& Challis, J.R.G. (1983) Prostaglandin output in relation to parturition by cells dispersed from human intrauterine tissues. Journal of Clinical Endocrinology and Metabolism 7, $694-699$.

Olson, D.M., Lye, S.L., Skinner, K. \& Challis, J.R.G. (1984) Early changes in prostaglandin concentrations in ovine maternal and fetal plasma, amniotic fluid and from dispersed cells of intrauterine tissues before the onset of ACTH-induced pre-term labour. Journal of Reproduction and Fertility 71, 45-55.

Olson, D.M., Lye, S.J., Skinner, K. \& Challis, J.R.G. (1985) Prostanoid concentrations in maternal/fetal plasma and amniotic fluid and intrauterine tissue output in relation to myometrial contractility during the onset of adrenocorticotropin-induced preterm labor in sheep. Endocrinology 116, 389-397.

Omini, C., Pasargiklian, R., Folco, G.C., Fano, M. \& Berti, F. (1978) Pharmacological activity of $\mathrm{PGI}_{2}$ and its metabolite 6-oxo-PGF ${ }_{1 \alpha}$ on human uterus and fallopian tubes. Prostaglandins 15, 1045-1054.

Omini, C., Folco, G.C., Pasargiklian, R., Fano, M. \& Berti, F. (1979) Prostacyclin (PGI-2) in pregnant human uterus. Prostaglandins 17, 113-119.

Randall, G.C.B., Taverne, M.A.M., Challis, J.R.G., Kendall, J.Z. \& Tsang, B.K.(1986) Interrelations between endocrine changes in peripheral and uterine venous blood and uterine activity at parturition in the pig. Animal Reproduction Science 11, 283-294.
Risbridger, G.P., Leach Harper, C.M., Wong, M.H. \& Thorburn, G.D. (1985) Gestational changes in prostaglandin production by ovine fetal trophoblast cells. Placenta 6, 117-126.

Robertson, H.A., Dwyer, R.J. \& King, G.J. (1985) Oestrogens in fetal and maternal fluids throughout pregnancy in the pig and comparisons with the ewe and cow. Journal of Endocrinology 106, 355-360.

SAS. 1982. SAS User's Guide: Basics. SAS Institute Inc., Cary, North Carolina.

Schatz, F. \& Gurpide, E. (1983) Effects of estradiol on prostaglandin $F_{2 \alpha}$ levels in primary monolayer cultures of epithelial cells from human proliferative endometrium. Endocrinology 113, $1274-1279$.

Schatz, F., Markiewicz, L., Barg, P. \& Gurpide, E. (1986) In vitro inhibition with antiestrogens of estradiol effects of prostaglandin $F_{2 a}$ production by human endometrium and endometrial cells. Endocrinology 118, 408-412.

Schatz, F., Markiewicz, L. \& Gurpide, E. (1987) Differential effects of estradiol, arachidonic acid and A23187 on prostaglandin $F_{2 \alpha}$ output by epithelial and stromal cells of human endometrium. Endocrinology 120, 1465-1471.

Silver, M., Barnes, R.J., Comline, R.S., Fowden, A.L., Clover, L. \& Mitchell, M.D. (1979) Prostaglandins in the foetal pig and prepartum endocrine changes in mother and foetus. Animal Reproduction Science 2, 305-322.

Steel, R.G. \& Torrie, J.H. (1980) Principles and Procedures of Statistics. McGraw-Hill Book Co. Inc., New York.

Strickland, D.M., Saeed, S.A., Casey, M.L. \& Mitchell, M.D. (1983) Stimulation of prostaglandin biosynthesis by urine of the human fetus may serve as a trigger for parturition. Science 220, 521-522.

Taverne, M.A.M. (1979) Physiological Aspects of Parturition in the Pig. PhD thesis, University of Utrecht.

Thorburn, G.D. \& Challis, J.R.G. (1979) Endocrine control of parturition. Physiology Reviews 59, 863-918.

Watson, J., Shepherd, T.S. \& Dodson, K.S. (1979) Prostaglandin E 2-9-ketoreductase in ovarian tissues. Journal of Reproduction and Fertility 57, 489-496.

Received 18 February 1991 